\title{
Pengaruh Perlakuan Jarak Tanam dan Pemberian Ekstrak Daun Mahkota Dewa Sebagai Penghambat Perkembangan Penyakit Antraknosa Pada Tanaman Cabai (Capsicum annum L)
}

\section{Effect of Treatment Plant Spacing and Giving Leaf Extract Mahkota Dewa As Antraknosa disease Growth Inhibitor At Chili Plants (Capsicum annuum L)}

\author{
Galvani Asep Santoni ${ }^{1}$, Iin Arsensi ${ }^{2}$ dan Mahdalena ${ }^{2}$ \\ ${ }^{1}$ Alumni Program Studi Agroteknologi, Fakultas Pertanian, Universitas Widya Gama Mahakam \\ Jl. KH. Wahid Hasyim, Sempaja, Samarinda, Kalimantan Timur, Indonesia. \\ ${ }^{2}$ Tenaga Pendidik Program Studi Agroteknologi, Fakultas Pertanian, Universitas Widya Gama Mahakam \\ email : avani@gmail.com, iin.azzah@gmail.com,mahdalen@yahoo.co.id
}

Diterima : 5 Mei 2016 Disetujui : 24 Juni 2016

\section{ABSTRACT}

Row spacing treatment had no significant effect on all parameters pengamatan.Pada age of 90 days after planting the average weight of the fresh fruit crop was obtained in treatment $\mathrm{j} 2$ highest ie $83.30 \mathrm{~g}$, while the average weight of the fresh fruit crop obtained at the lowest possible j3 treatment of 75,49 g.Perlakuan extract of petals gods were not significantly affected all parameters pengamatan.Pada age of 90 days after planting the average weight of the fresh fruit crop was obtained in treatment dl highest ie $83.98 \mathrm{~g}$, while the average weight of the fresh fruit crop lowest was obtained in treatment that is 77.52 g.Interaksi d0 between the treatment plant spacing and crown god leaf extract had no significant effect on all parameters of observation. At the age of 90 days after planting the average percentage of disease were highest in j2d2 treatment combination that is $65.64 \%$ while the average percentage of the lowest in disease treatment combination j2d0 yaitu $51.72 \%$. This research was conducted by randomized block design factorial $4 \times 3$ with three replications. The first factor is a spacing (A) which consists of three levels ie; $j 1(60 \times 60 \mathrm{~cm}), j 2(60 \times 70 \mathrm{~cm})$ and $j 3(60 \times 80 \mathrm{~cm})$. The second factor is the extract of leaves of the gods crown (D), which consists of four levels ie; $d 0$ (control), d1 (2 ml / liter of water), $d 2$ (4 ml / liter of water) and $\mathrm{d} 3$ (6 $\mathrm{ml} /$ liter of water).

Keywords: Leaf Extract Mahkota Dewa inhibitors Antraknosa

\section{PENDAHULUAN}

Cabai merah (Capsicum annum L) merupakan salah satu komoditas sayuran penting.Cabai merah dikenal sebagai bahan penyedap masakan dan pelengkap berbagai menu masakan khas Indonesia.Kebutuhan akan komoditas ini semakin meningkat sejalan dengan makin bervariasinya jenis dan menu masakan yang memanfaatkan produk ini. Selain itu juga karena semakin ditingkatkannya ekspor komoditas non migas (Nawangsih dkk, 2003).Cabai merah tidak hanya mengandung zat rasa pedas tetapi juga banyak mengandung vitamin dan mineral yang berguna untuk kesehatan tubuh manusia (Pracaya, 2003).Cabai juga banyak mengandung gizi berupa protein dan vitamin yang berguna bagi tubuh.Kandungan gizi cabai merah segar per 100 gram terdiri dari $31,0 \mathrm{kal} ; 1,0$ gram protein; 0,3 gram lemak; 7,3 gram karbohidrat; 29,0 mg Kalsium; 24,0 mg Fosfor; 0,5 mg Besi; $470 \mathrm{mg}$ Vitamin; 18,0 mgVitamin C; 0,05 mgVitamin B1; 0,03 mg Vitamin B2; 0,20 mg Niasin; 0,11,5\% kapsaikin; $2,33 \%$ pektin; $8,57 \%$ pentosan;
0,8-1,4\% pati (Bernardinus dan Wiryanta, 2002).

Adanya serangan OPT (Organisme Penggangu Tanaman) yang cenderung meningkat telah mampu dikendalikan oleh petani dengan penggunaan pestisida relatif cukup tinggi.Hal ini menyebabkan biaya produksi meningkat (Anonim, 2006).

Serangan hama dan penyakit merupakan salah satu faktor yang dapat menghambat kelancaran dalam budidaya cabai.Salah satu jenis penyakit yang sering menyerang pada tanaman cabai adalah penyakit antraknosa.Penyakit ini disebabkan oleh jamur Coletotrichum sp, yang pada tingkat serangan tertentu dapat merugikan hasil yang cukup besar juga dapat menghancurkan seluruh tanaman (Semangun, 2000).

Antraknosa disebabkan oleh jamur dari genus Colletotrichum yang merupakan kelompok yang umum dari patogen tanaman dan jamur ini penyebab penyakit pada banyak spesies tanaman di seluruh dunia.Identifikasi spesies Colletotrichum biasanya lebih dari satu karakteristik, diantaranya bentuk fisiknya, 
kepatogenisitasnya pada tanaman inang.Banyak spesies dari Colletotrichum menginfeksi lebih dari satu tanaman inang dan untuk memudahkan identifikasi ada 3 spesies dari Colletotrichum yaitu C.gloeosporioides, C.capsici dan C.cocodes yang menyebabkan penyakit pada tanaman cabai di Florida (Semangun, 2000).

Antraknosa adalah penyakit terpenting yang menyerang cabai di Indonesia.Penyakit ini distimulir oleh keadaan lembab dan suhu relatif tinggi.Penyakit antraknosa dapat menyebabkan kerusakan sejak dari persemaian sampai tanaman cabai berbuah dan merupakan masalah utama pada buah masak, serta berakibat serius terhadap penurunan hasil dan penyebaran penyakit.Pada musim hujan kehilangan hasil pertanaman cabai akibat serangan antraknosa dapat mencapai 50-100\% (Syamsudin, 2007).

Pengendalian penyakit terutama yang disebabkan oleh jamur selama ini dilakukan secara kimiawi dengan menggunakan fungisida.Cara pengendalian penyakit antraknosa dengan menggunakan fungisida memang lebih praktis bila dibandingkan dengan cara pengendalian lain (Semangun, 2000).

Pengetahuan akan teknik budidaya diantaranya pengaturan jarak tanam, karena pengaturan jarak tanam termasuk komponen PHT (Pengendalian Hama Terpadu) dalam pengendalian secara kultur teknis. Jarak tanam ditentukan berdasarkan jenis cabai yang ditanam.Berdasarkan pengamatan dilapangan, jarak tanam yang lebar akan lebih baik untuk kesehatan tanaman. Bila menggunakan jarak tanam yang rapat atau sempit, situasi disekitar

\section{BAHAN DAN METODE}

Lokasi penelitiandi lahan praktek UPTB BAPELTAN, dalam pelaksanan penelitian ini menggunakan lahan dengan panjang 15 meter dan lebar 6 meter. Bahan yang digunakan adalah bibit cabai berumur 21 hari, Arang sekam padi, Tanah lapisan atas, Daun mahkota dewa, Pupuk kandang ayam, Pupuk ZA, Roundup, Pupuk NPK mutiara (16:16:16). Penelitian disusun dalam Rancangan Acak Kelompok (RAK) dengan percobaan Faktorial 4 x 3 dengan 3 ulangan. Faktor pertama adalah jarak tanam (J) yang terdiri dari 3 taraf yaitu : j1; $60 \times 60 \mathrm{~cm}$, j2; 60 × $70 \mathrm{~cm}$ dan j3; 60 x $80 \mathrm{~cm}$. Faktor kedua adalah pemberian ekstrak daun mahkota dewa (D) yang terdiri dari 4 taraf yatu : $\mathrm{d}_{0}$; control, $\mathrm{d}_{1} ; 2 \mathrm{ml} /$ liter air, $\mathrm{d}_{2} ; 4 \mathrm{ml} /$ liter air dan $\mathrm{d}_{3} ; 6 \mathrm{ml} / \mathrm{liter}$ air. Pelaksanaan penelitian meliputi : penyiapan lokasi penelitian dan persemaian, pemasangan patok/ ajir, pembuatan bedengan, pemupukan awal, pemasangan mulsa, ekstraksi daun mahkota dewa, penanaman, pemeliharaan (penyiraman, penyiangan, penyulaman, pemasangan ajir, perempelan, tanaman akan menjadi lembab. Situasi yang demikian akan dapat mengundang datangnya jamur. Selain tanah menjadi lembab, jarak tanam yang rapat akan berpengaruh terhadap pertumbuhan cabang dan ranting tanaman. Hal ini secara tidak langsung akan mempengaruhi produksi buah nantinya. Populasi tanaman ditentukan oleh jarak tanam yang mempengaruhi produksi karena peningkatan kerapatan tanam persatuan luas sampai batas tertentu akan meningkatkan hasil, akan tetapi peningkatan jumlah tanaman juga dapat menurunkan hasil karena terjadi kompetisi air, unsur hara, cahaya matahari, ruang tumbuh sehingga akan mengurangi suplai makanan ke tanaman (Irfan, 1999).

Ciri daun mahkota dewa berdaun tunggal, bertangkai pendek, tersusun berhadapan (folia oposita), warna hijau tua, bentuk jorong hingga lanset, panjang 7-10 cm, lebar 2-2,5 cm, helai daun tipis, ujung dan pangkal runcing, tepi rata, pertulangan menyirip (pinnate), permukaan licin, tidak pernah meluruh bunga tunggal, muncul di sepanjang batang dan ketiak daun, bertangkai pendek, mahkota berbentuk tabung (tubulosus) - berwarna putih buah bulat, panjang 3-5 cm, buah muda berwarna hijau setelah tua menjadi merah (Anonim , 2004).

Bahanantioksidan alami yang terdapat pada tanaman mahkota dewamemiliki potensi sebagai fotoprotektor. Antioksidan dapat memberikan perlindungan bila diaplikasikan baik secara sistemik maupun secara langsung (Harmanto, 2002).

pemberian ekstrak daun mahkota dewa, pemupukan susulan dan panen. Pengambilan data dilakukan dengan mengambil data tinggi tanaman, berat buah per tanaman, jumlah buah yang terserang penyakit dan persentase serangan Persentase serangan buah yang terkena penyakit dilakukan dengan menggunakan rumus yang dimodifikasi dari (Girsang, 2008) :

$$
\mathrm{P}=\quad \frac{a}{b} \times 100 \%
$$

Dimana :

$\mathrm{P}$ : Persentase serangan penyakit

a : jumlah buah yang terserang penyakit

b : jumlah seluruh buah/tanaman

Skoring presentasi serangan penyakit:

$$
\begin{array}{lll}
- & 0-20 \% & =\text { Tahan. } \\
- & 21-40 \% & =\text { Agak Tahan. } \\
- & 41-50 \% & =\text { sedang. } \\
- & >50 \%=\text { Peka. }
\end{array}
$$

Sumber : (Syukur, 2007) 


\section{HASIL DAN PEMBAHASAN}

\section{Pengaruh Jarak Tanam}

\section{Tinggi Tanaman.}

Hasil sidik ragam menunjukkan bahwa perlakuan jarak tanam tidak berbeda nyata terhadap rata-rata tinggi tanaman umur 30, 60 dan 90 hari setelah tanam. Pada umur 90 hari setelah tanam perlakuan $j_{1}$ memberikan hasil yang tertinggi pada parameter tinggi tanaman yaitu $(54,06 \mathrm{~cm})$, sedangkan perlakuan $\mathrm{j}_{3}$ memberikan hasil yang terkecil pada parameter tinggi tanaman yaitu $(51,70 \mathrm{~cm})$. Walaupun tidak berbeda nyata tetapi perbedaan tinggi tanaman pada masing-masing perlakuan memperlihatkan terjadi kompetisi antar tanaman.

Menurut Indriyanto (2006), bahwa persaingan dilakukan oleh organisme-organisme dalam memperebutkan kebutuhan ruang (tempat), makanan, unsur hara, air, sinar, udara, agen penyerbukan atau faktor-faktor ekologi lainnya sebagai sumber daya yangdibutuhkan oleh tiap-tiap organisme untuk hidup dan pertumbuhannya.

Pengaturan populasi tanaman melalui pengaturan jarak tanam pada suatu pertanaman akan mempengaruhi keefisienan tanaman dalam memanfaatkan matahari dan persaingan tanaman dalam memanfaatkan hara dan air yang pada akhirnya mempengaruhi pertumbuhan dan produksi tanaman (Musa dkk., 2007).

Kerapatan atau ukuran populasi tanaman sangat penting untuk memperoleh hasil yang optimal, tetapi dapat terjadi persaingan dalam hara, air dan ruang tumbuh serta mengurangi perkembangan tinggi dan kedalaman akar tanaman (Nasir, 2010).

\section{Berat Buah Segar/Tanaman.}

Hasil sidik ragam menunjukkan bahwa perlakuan jarak tanam tidak berbeda nyata terhadap rata-rata berat buah segar/tanaman umur 75 dan 90 hari setelah tanam. Pada umur 75 hari setelah tanam perlakuan $\mathrm{j} 1$ memberikan hasil berat buat segar tertinggi yaitu 164,13 g, sedangkan perlakuan j3 memberikan hasil berat buah segar terkecil yaitu $107,90 \mathrm{~g}$. Hal ini diduga bahwa pada jarak tanam yang terlalu lebar populasi tanaman menjadi sedikit dan akhirnya akan mempengaruhi produksi tanaman.

Sesuai dengan pernyataan Rafi (1996), bahwa peningkatan jumlah buah per tanaman, hasil panen per hektar dipengaruhi oleh kepadatan tanaman. Hal ini merupakan indikasi bahwa pada kepadatan tanam tinggi, kinerja individu tanaman menurun namun jumlah tanaman yang lebih banyak dari tanaman per satuan luas dapat menutupi kemampuan individu tanaman yang rendah.Kepadatan penanaman yang lebih rendah per satuan luas menghasilkan tanaman lebih kuat daripada kepadatan yang lebih tinggi, namun ini tidak bisa menggantikan dampak penurunan jumlah tanaman per satuan luas. Pada umur 90 hari setelah tanam perlakuan j2 memberikan hasil yang terbaik yaitu 83,30 gram, sedangkan perlakuan $\mathrm{j} 3$ memberikan hasil yang terkecil yaitu 75,49 gram. Hal ini diduga bahwa pada jarak tanam yang terlalu lebar tidak efisien dalam pemanfaatan lahan, kerena pada penanaman dengan jarak tanam yang terlalu lebar kurang menguntungkan dalam hasil produksi dikarenakan populasi tanaman menjadi lebih sedikit. Hal tersebut sesuai dengan pernyataan Ganesan dan Subbiah (2004), bahwa rata-rata bobot buah, jumlah buah per tanaman dan hasil per tanaman meningkat dengan jarak tanam yang lebih dekat dibandingkan dengan jarak tanam lebih lebar.Jarak tanam yang lebih dekat memberikan hasil tertinggi. Jarak tanam yang lebih dekat menghasilkan produksi jumlah buah per tanaman lebih banyak dan meningkatkan bobot buah rata-rata.

\section{Jumlah Buah yang Terserang Penyakit}

Hasil sidik ragam menunjukkan bahwa perlakuan jarak tanam tidak berbeda nyata terhadap rata-rata jumlah buah yang terserang penyakit umur 75 dan 90 hari setelah. Pada umur 75 hari setelah tanam jumlah buah yang terserang penyakit tertinggi dicapai pada perlakuan j2 yaitu 58,50 buah, sedangkan pada umur 90 hari setelah tanam jumlah buah yang terserang penyakit tertinggi dicapai pada perlakuan j1 yaitu 37,00 buah. Hal ini didugapada populasi tanaman yang semakin tinggi diikuti juga dengan peningkatan suhu mikro. Semakin tinggi tingkat kerapatan tanaman maka suhu lingkungan tumbuhpun menjadi meningkat, sehingga kelembaban tanah meningkat yang pada akhirnya jamur akan mudah berkembang biak. Khalid dkk (2009), mengemukakan bahwa fluktuasi populasi jamur pada area pertanaman dapat dipengaruhi oleh beberapa faktor seperti cuaca, kekuatan tanaman, tanaman inang dan tanaman sekitar inang.Hal ini didukung oleh Rafi (1996), yang menyebutkan bahwa dengan kepadatan penanaman yang lebih rendah per satuan luas 
menghasilkan tanaman lebih kuat daripada kepadatan yang lebih tinggi.

Jumlah buah semakin menurun seiring bertambahnya individu tanaman.Hal ini dikarenakan jumlah buah per tanaman dipengaruhi oleh kerapatan tanaman serta nutrisi yang terkandung dalam tanah.MenurutRafi (1996), dengan kerapatan tanaman yang tinggi akan menurunkan jumlah buah yang dihasilkan tiap individu tanaman.

\section{Persentase Serangan Penyakit Pada Tanaman Cabai}

Rata-rata persentase serangan penyakit umur 75 hari setelah tanam adalah 54,62 \%, sedangkan rata-rata persentase serangan penyakit umur 90 hari setelah tanam adalah $56,34 \%$. Hal ini didugapada populasi tanaman yang semakin tinggi diikuti juga dengan peningkatan suhu mikro.Khalid dkk (2009), mengemukakan bahwa fluktuasi populasi jamur pada area pertanaman dapat dipengaruhi oleh beberapa faktor seperti cuaca, kekuatan tanaman, tanaman inang dan tanaman sekitar inang.Hal ini didukung oleh Rafi (1996), yang menyebutkan bahwa dengan kepadatan penanaman yang lebih rendah per satuan luas menghasilkan tanaman lebih kuat daripada kepadatan yang lebih tinggi.

Tanaman cabai merupakan tanaman yang rentan terhadap serangan hama dan penyakit, terutama pada saat memasuki fase generatif.Penyakityang sering menyerang adalah penyakit antraknosa yang disebabkan oleh jamur.Timbulnya penyakit ini dipicu oleh suasana iklim di areal penanaman yang lembab, temperatur tinggi, cuaca berkabut dan berembun. Menurut Jumin (2002), jarak tanam yang terlalu rapat akan mengakibatkan lingkungan tumbuh tanaman menjadi lembab karena cahaya matahari tidak dapat menembus permukaan tanah yang disebabkan tajuk yang menyatu. Dengan kondisi lingkungan tumbuh yang lembab akan mempercepat tumbuhnya jamur penyebab penyakit tersebut yang pada akhirnya akan berpengaruh pada produksi tanaman.

Gejala penyakit yang ditemukan saat penelitian adalahantraknosa atau petek yang disebabkan oleh cendawan Coletroticum capsici, biasanya menyerang tanaman dengan menginfeksi jaringan buah dan membentuk bercak coklat kehitaman yang kemudian meluas menjadi busuk lunak.Serangan yang berat menyebabkan buah mengering dan keriput seperti jerami, penyakit ini ditandai dengan buah busuk berwarna kuning-coklat seperti terkena sengatan matahari diikuti oleh busuk basah yang terkadang berwarna hitam.Sedangkan pada biji dapat menimbulkan kegagalan berkecambah atau bilah menjadi kecambah dapat menimbulkan rebah kecambah.Pada tanaman dewasa dapat menimbulkan mati pucuk, infeksi lanjut ke bagian lebih bawah yaitu daun dan batang yang menimbulkan busuk kering warna coklat kehitam-hitaman (Semangun, 2006).

\section{Pengaruh Ekstrak Daun Mahkota Dewa}

\section{Tinggi Tanaman.}

Hasil sidik ragam menunjukkan bahwa pemberian ekstrak daun mahkota dewa tanam tidak berbeda nyata terhadap rata-rata tinggi tanaman umur 30, 60 dan 90 hari setelah tanam. Pada umur 90 hari setelah tanam perlakuan d0 memberikan hasil yang tertinggi yaitu $(53,79)$ sedangkan perlakuan d2 memberikan hasil yang terkecil yaitu $(51,85)$ Hal ini diduga bahwa pemberian ekstrak daun mahkota dewa belum mampu memberikan pengaruh yang signifikan terhadap pertumbuhan tanaman cabai.

Sesuai dengan pendapat Lingga dan Marsono (2010), suatu tanaman akan tumbuh subur bila elemen yang tersedia cukup dan sesuai dengan kebutuhan tanaman, penambahan unsur hara yang tepat akan menghasilkan pertumbuhan vegetatif maupun generatif yang sebanding dengan unsur hara yang diberikan. Ditambahkan oleh (Hardjowigeno, 2007), yang menyatakan pertumbuhan dan perkembangan tanaman membutuhkan kebutuhan hidup yaitu unsur hara, air, cahaya matahari dan ruang yang cukup tersedia.

\section{Berat Buah Segar/Tanaman.}

Hasil sidik ragam menunjukkan bahwa pemberian ekstrak daun mahkota dewa tidak berbeda nyata terhadap rata-rata berat buah segar/tanaman umur 75 dan 90 hari setelah tanam. Berat buah segar/tanaman tertinggi pada umur 75 hari setelah tanam dicapai pada perlakuan d1 yaitu 156,74 g, sedangkan pada umur 90 hari setelah tanam dicapai pada perlakuan d1 yaitu 83,98 g.Hal ini diduga bahwa penggunaan ekstrak daun mahkota dewa dengan konsentrasi yang diberikan belum dapat menekan serangan penyakit yang menyerang pada tanaman cabai, sehingga belum dapat meningkatkat produktivitas tanaman cabai secara maksimal. Sesuai dengan pendapat Syamsudin (2007), bahwa antraknosa adalah penyakit terpenting pada tanaman cabai.Penyakit ini distimulir oleh kondisi 
lembab dan suhu relatif tinggi.Penyakit antraknosa dapat menyebabkan kerusakan sejak dari persemaian sampai tanaman cabai berbuah dan merupakan masalah utama pada buah masak, serta berakibat serius pada penurunan hasil tanaman.

\section{Jumlah Buah yang Terserang Penyakit.}

Hasil sidik ragam menunjukkan bahwa pemberian ekstrak daun mahkota dewa tidak berbeda nyata terhadap rata-rata jumlah buah yang terserang penyakit umur 75 dan 90 hari setelah tanam, serta rata-rata persentase serangan penyakit. Jumlah buah yang terserang penyakit tertinggi pada umur 75 hari setelah tanam terdapat pada perlakuan d3 yaitu $(68,78)$ sedangkan pada umur 90 hari setelah tanam yaitu pada perlakuan d2yaitu $(36,89)$. Hal ini diduga bahwa pemberian ekstrak daun mahkota dewa belum mampu menekan perkembangan penyakit pada tanaman cabai.Selain itu kondisi lingkungan tumbuh yang lembab selama penelitian menyebabkan perkembangan spora cendawan penyebab penyakit berkembang dengan cepat, sehingga berpengaruh pada produktivitas tanaman. Menurut Apoendi (1991), bahwa pertumbuhan tanaman merupakan perpaduan antara susunan genetis dengan lingkungannya, sehingga respon terhadap lingkungan yang rendah dapat menurunkan pertumbuhan, akibatnya tanaman tersebut tumbuh rendah. Kondisi lingkungan yang tidak baik akan mempengaruhi perkembangan dan produktivitas tanaman. Persentase Serangan Penyakit Pada Tanaman Cabai. Rata-rata persentase serangan penyakit umur 75 hari setelah tanam adalah 54,62 \%, sedangkan rata-rata persentase serangan penyakit umur 90 hari setelah tanam adalah 56,34 \%.Hal ini diduga bahwa pemberian ekstrak daun mahkota dewa belum mampu menekan perkembangan penyakit pada tanaman cabai.Selain itu kondisi lingkungan tumbuh yang

\section{KESIMPULAN}

1. Perlakuan jarak tanam tidak berpengaruh nyata terhadap semua parameter pengamatan. Rataan presentase serangan penyakit antraknosa yang terendah untuk umur 75 hari setelah tanam pada perlakuan j1yaitu 52,08\% dan umur 90 hari setelah tanam yang terendah yaitu j3yaitu 30,00\%.

2. Perlakuan pemberian ekstrak daun mahkota dewa tidak berpengaruh nyata terhadap semua parameter pengamatan. Rataan presentase serangan penyakit antraknosa lembab selama penelitian menyebabkan perkembangan spora cendawan penyebab penyakit berkembang dengan cepat. Menurut Sinaga (2000), pembentukan penyakit sangat ditentukan oleh tiga komponen yang selalu berinteraksi.Komponen penyakit tumbuhan yaitu patogen, inang dan lingkungan abiotik dan biotik.Komponen-komponen tersebut dapat berubah-ubah sifatnya, sehingga bila satu komponen saja berubah maka akan mempengaruhi tingkat serangan penyakit pada inangnya.

\section{Pengaruh Interaksi Perlakuan}

Hasil sidik ragam menunjukkan bahwa pengaruh interaksi jarak tanam dan pemberian ekstrak daun mahkota dewa tidak berbeda nyata terhadap semua variabel penelitian yaitu tinggi tanaman, berat buah segar/tanaman, jumlah buah yang terserang penyakit dan persentase serangan penyakit. Keadaan ini menunjukkan bahwa antara faktor jarak tanam dan pemberian ekstrak daun mahkota dewa tidak secara bersama-sama dalam menekan perkembangan penyakit pada tanaman cabai atau dengan kata lain kedua faktor perlakuan tersebut memberikan pengaruh secara terpisah dan bertindak bebas satu terhadap lainnya.Seperti yang dikemukan oleh Gomez dan Gomez (1995), bahwa dua faktor dikatakan berinteraksi apabila pengaruh suatu faktor perlakuan berubah pada saat perubahan taraf faktor perlakuan lainnya. Tidak adanya perbedaan nyata ini karena perlakuan jarak tanam dan pemberian ekstrak daun mahkota dewa tidak terdapat hubungan saling mempengaruhi, kedua faktor perlakuan tersebut bertindak bebas satu sama lainnya.Menurut Steel dan Torie (1993), apabila interaksi antara perlakuan yang satu dengan yang lain tidak berbeda nyata, maka dapat disimpulkan bahwa faktor-faktor tersebut bertindak bebas satu sama lain, pengaruh sederhana suatu faktor sama pada semua taraf faktor lainnya.

yang terendah untuk umur 75 hari setelah tanam pada perlakuan d2 yaitu $41,44 \%$ dan umur 90 hari setelah tanam yang terendah yaitu d0 yaitu $31,11 \%$.

3. Interaksi antara perlakuan jarak tanam dan pemberian ekstrak daun mahkota dewa tidak berpengaruh nyata terhadap semua parameter pengamatan.Rataan presentase serangan penyakit antraknosa yang terendah untuk umur 75 hari setelah tanam pada perlakuan j2d0 yaitu $29,33 \%$ dan umur 90 hari setelah tanam yang terendah yaitu j3d2 yaitu $27,33 \%$. 


\section{DAFTAR PUSTAKA}

Anonim. 2006. Produksi Tanaman Cabai Nasional.www.deptan go.id.

2014.http://www.tanobat.com/mahkotadewa-ciri-ciri-tanaman-serta-khasiat-danmanfaatnya.html. Di akss pada 13 November 2015 di samarinda

Apoendi, M. 1991. Pengantar Agronomi. Erlangga. Jakarta.

Bernaditus Y.dan W Wiryanta. 2002. Bertanam Cabai di Musim Hujan.Penebar Swadaya. Jakarta.

Ganesan, M and Vijay R.Subbiah. 2004. A Case study on increasing tomato productivity in a Low cost naturally ventilated Greenhouse with different spacing.

Gomez, K.A dan A.A Gomez. 1995. Prosedur Statistika untuk Penelitian Pertanian (Terjemahan a.Sjamsuddin \& J.S Baharsyah).Edisi Kedua. UI Press. Jakarta.

Hardjowigeno, S. 2007. Ilmu Tanah. .Akademika Pressindo. Jakarta.

Harmanto, N. 2002. Sehat dengan Ramuan Tradisional Mahkotadewa.Cetakan Ke empat, Tangerang. PT.Agromedia Pustaka. Jakarta.

Indriyanto. 2006. Ekologi Hutan. Bumi Aksada. Jakarta.

Irfan, M. 1999. Respon Tanaman Jagung (Zea mays L) Terhadap Pengolac han Tanah dan Kerapatan Tanam Pada Tanah Andosol dan Ultisol. Pasca Sarjana Universitan Sumatera Utara. Medan.

Jumin, H.B. 2002. Dasar-Dasar Agronomi. Rajawali Press. Jakarta.

Khalid, S.A.N, M.N.Mohamad Roff and A.B.Idris. 2009. Population Abundance of AlateWhitefly, (Bemisia Tabaci Gennadius)in Chilli (Capsicum annuum L.) ecosystem. J. Trop. Agric.and Fd. Sc.37(2)(2009):263S-a2e7ed0
Lingga P, dan Marsono. 2010. Petunjuk Penggunaan Pupuk. Penebar Swadaya. Jakarta.

Musa Y., Nasarudin, dan M.A.Kuruseng. 2007. Evaluasi Produktivitas Jagung Melalui Pengelolaan Populasi Tanaman, Pengolahan Tanah dan Dosis Pemupukan. Agrisistem 1: 21-33.

Nasir, A. 2010.Pengaruh Jarak Tanam terhadap Pertumbuhan dan Perkembangan Tanaman.(http://ahmadnasir.blogspot.com/j arak tanam.htm.)Diakses pada tanggal 20Juli2015.p 100-102

Nawangsih A.A, Purwanto H.I, Wahyudi A. 2003. Cabai Hot Beauty.Penebar Swadaya. Jakarta.

Pracaya. 2003. Bertanam Lombok. Kanisius. Yogyakarta.

Rafi, U.M. 1996. Stem Pruning and Spacing Effect on Yield of Tomato. In: ARCAVRDC training report. pp: 168-173.

Sinaga, M.S. 2000. Dasar-Dasar Ilmu Penyakit Tanaman.Diktat kuliah, Jurusan Hama dan Penyakit Tumbuhan.Institut Pertanian Bogor..

Semangun, H. 2000. Penyakit-penyakit Tanaman Hortikultura di Indonesia. Edisi ke-4.Gadjah Mada University Press, Yogyakarta. , H. 2006. Pengantar Ilmu Penyakit Tumbuhan. Gadjah Mada University Press. Yogyakarta.

Steel, R.G. D. andTorrie, J. H. 1993.Principles and Procedur of Statistic (Terjemahan Bambang Sumantri, Prinsip dan Prosedur Statistika).Gramedia. Jakarta.

Syamsudin. 2007. Pengendalian Penyakit Terbawa Benih (seed born diseases) pada Tanaman Cabai (Capsicum annuum L) Menggunakan Agen Biokontrol dan Ekstrak Botani.Agrobio 2. 